\title{
三次元空間情報による異常振動の解析*
}

\author{
小 村 英 智*1, 下，村 和 広*2 \\ 芝田.和 雄*1, 中 川 紀 壽*3
}

\section{Analysis of Faulty Vibration by Three-Dimensional Information}

\author{
Hidemichi KOMURA*4, Kazuhiro SHIMOMURA, \\ Kazuo SHIBATA and Noritoshi NAKAGAWA \\ *4 Machine Diagnosis Technology Department, Rion Co., Ltd. \\ 3-20-41 Higashimotomachi, Kokubunji-shi, Tokyo, 185-8533 Japan
}

\begin{abstract}
Some kind of machine faults such as unbalance, misalignment, looseness, and eccentricity occupy the most part of the category of fault of structure. It is important to diagnose these faults accurately to prevent the recurrence of the same fault. The unbalance includes static unbalance, couple unbalance, quasi-static unbalance and dynamic unbalance. The misalignment includes parallel misalignment and angular misalignment. In any fault of structure, vibrations both perpendicular and parallel to the rotation shaft occur, and the directional characteristics of vibration change with the type of machine fault. If we measure vibrations in three directions by a conventional unidirectional type of vibrometer, the measured data does not include enough information for diagnosis. It is extremely difficult to diagnose the fault of structure accurately only by this information. It is necessary to observe and analyze the movement of measured point in order to diagnose the fault and search its causes by using three directional information processing technology that measures orthogonal three directional vibrations simultaneously and uses the phase information among them. To realize it, the analysis technique of vibration information in 3-dimensional space is necessary. In this paper, we describe a new hand-held type triaxial vibrometer and its pickup. The operation principle is quite different from conventional triaxial pickups. A detailed operation principle of the new pickup is reported. Finally we propose new display method and data processing technique of vibration in 3 -dimensional space.
\end{abstract}

Key Words : Fault of Structure, Rotating Machinery, Triaxial Vibration Pickup, Elliptical Orbit, 3-Dimensional Display

\section{1. 緒言}

回転機械のメンテナンスを行うとアンバランス，ミ スアライメント，ガタ，偏心は構造系故障の大部分を 占めている。これらの故障を的確に診断することは故 障を再発させないために重要な課題である.

アンバランスの中にも静アンバランス，偶カアンバ ランス, 動的アンバランスなどがある. ミスアライメ ントにも芯ずれミスアライメントと面ずれミスアライ メントがある、これら故障は回転軸に直角な方向およ び軸方向の振動を発生するが，故障によって軸受に現 れる振動の動態が異なる．従来使われている一方向だ け測れる振動計を用いて三方向の振動を測定すること もあるが，それだけの情報では診断を的確に行うこと は極めて難しい，直交3軸の振動を同時に測定し，その 三次元空間の振動情報を用いて測定点の動態を観測し て解析することが異常原因を探求するために理想的な 方法である。そのためには三次元空間の簡便な測定手

* 原稿受付 2002 年 5 月 30 日

*1 正員, リオン(株)設徣診断開発室(画185-8533 国分寺市東 元町 3-20-41).

*2 リオン(株)設備診断開発室.

*3 正員, 広島大学大学院 (五 739-8527 東広島市鏡山 1-4-1).

E-mail : komura@rion.co.jp
段と, 三次元空間の振動情報の解析手法が必要である. 本論文は，新たな原理による押当式の3軸振動ピッ クアップと，その振動ピックアップを搭載した振動計 について述べ, 最後にこの振動計で測定した三次元空 間の振動データの新たな表示法と演算処理方法を提案 するものである。

\section{2. 振動ピックアップの動作原理 ${ }^{(1) .(2)}$}

$2 \cdot 1$ 水平振動の険出図1に水平面に沿って運動 している面に棒を押し当てた時の棒の運動を示亦，棒 上のB点から左右の等距離の点をEおよびNとする． $\mathrm{E}$ 点とN点に振動センサ素子を取り付けて，その受感軸 が棒の先端Uと角度 $\theta$ で交わる構造とする.棒の先端U が平面方向の水平振動をしている面に押し付けられる と, E点およびN点は平面方向に運動すると同時に, 中 心線がO点を支点に傾斜するためにB点を中心とした ロッキング運動をする.この場合, E点と N点の振動セ ンサ各素子は水平方向の運動とロッキング運動が合成 された運動のUE, UN方向八の成分の信号を検出する.

図2はE点の運動を用いて新たな押当式3軸振動ピッ クアップの動作原理を示すものである，図2で，O点を 座標の原点としUO方向に $z$ 軸, 直交する左右方向にy 

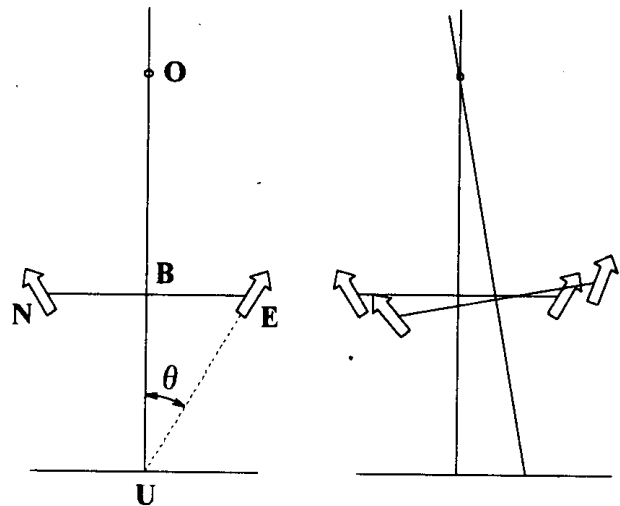

Fig. 1 Motion of a bar on horizontally moving surface 軸をとる。

$\mathrm{B}, \mathrm{U}$ 点の $z$ 軸上の座標を $b, u$ とし，E点の $y$ 軸上の座 標を $e$ よする，先端Uが関数 $y_{U}(t)$ でy軸方向に振動する 上，E点のセンサはE点でのy方向運動で発生する成分 $y_{E}(t)$ とロッキング運動で発生する成分 $z_{E}(t)$ のそれぞ れのUE方向成分を同時に検出する，従って，センサE の検出信号 $p_{E}(t)$ は

$$
p_{E}(t)=y_{E}(t) \sin \theta+z_{E}(t) \cos \theta
$$

である．先端Uが $y$ 方向に運動するときの原点Oの振角 を $\delta(t)$ とするとB点の $y$ 方向の振幅 $y_{E}(t)$ はOB間の距離 $\mathrm{b}$ と振角の積

$$
y_{E}(t)=b \sin \delta(t)
$$

となる．同様にE点のロッキング運動による振幅 $z_{E}(t)$ はBE間の距離 $\mathrm{e}$ と振角の積で求められ

$$
z_{E}(t)=e \sin \delta(t)
$$

となる。これを(1)式に代入すると

$$
p_{E}(t)=(b \sin \theta+e \cos \theta) \sin \delta(t)
$$

となり,さらに $b=u-e \cos \theta / \sin \theta$ の関係から，(3)式 は

$$
p_{E}(t)=u \sin \theta \cdot \sin \delta(t)
$$

となる。(2)式と同様に幾何的な関倸から

$$
\sin \delta(t)=y_{U}(t) / u
$$

が得られる。(4)式上(5)式から点で検出される信号は。

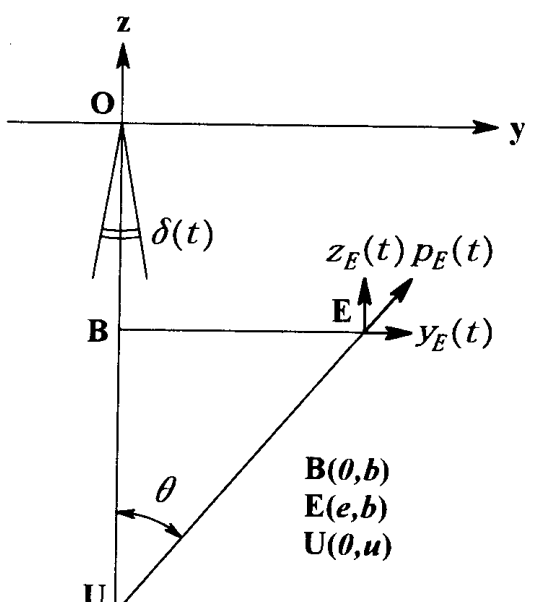

Fig.2 Operation principle

$$
p_{E}(t)=y_{U}(t) \sin \theta
$$

となり，E点のセンサが検出する信号 $p_{E}(t)$ は受感軸と 中心線の交差角 $\theta$ だけに依存する関数となる。この交 差角 $\theta$ は構造的に決めることができる。

$2 \cdot 2$ 水平と垂直振動の検出 接触点Uが垂直. $(z)$ 方 向に $z_{U}(t)$ で運動しているときのセンサの検出信号は 幾何的な関係だけによって決まり， $z_{U}(t) \cos \theta$ である。 したがって，接触点Uが水平運動と垂直運動を同時に 行っているときにEに取り付けられたセンサで検出さ れる信号は，

$$
p_{E}(t)=y_{U}(t) \sin \theta+z_{U}(t) \cos \theta
$$

となる. Eと対称な位置Nのセンサの検出信号は垂直方 向の運動についてはEのセンサの検出信号とまったく 同じであるが, 水平方向運動については逆位相であり，

$$
p_{N}(t)=-y_{u}(t) \sin \theta+z_{U}(t) \cos \theta
$$

となる.(7)式および(8)式の和および差からそれぞれ垂 直方向と水平方向の運動成分が求められる.

垂直成分は

$$
z_{U^{\prime}}(t)=\frac{p_{E}(t)+p_{N}(t)}{2 \cos \theta}
$$

であり，水平成分は次式となる。

$$
y_{U}(t)=\frac{p_{E}(t)-p_{N}(t)}{2 \sin \theta}
$$

$2 \cdot 3$ 水平2方向と垂直振動の検出直交する水平2 方向と垂直方向の振動を検出するための構造を図3に 示す．三方向の振動は垂直方向の $z$ 軸の周りに間隔 $\eta$ $(=2 \pi / 3)$ 毎に3個のセンサを配置して, 幾何的な補正 を施すだけで得られる．接触点Uが垂直方向 ( $z$ 方向)に $z_{U}(t)$ ，水平方向 $\left(y\right.$ 方向)に $y_{U}(t), y$ 方向に直交する水平 方向 $\left(x\right.$ 方向)に $x_{U}(t)$ で運動しているときの，セン少 1 ,

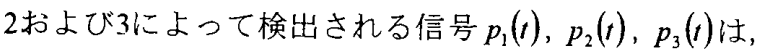

$$
\begin{aligned}
& p_{1}(t)=y_{U}(t) \sin \theta+z_{U}(t) \cos \theta \\
& p_{2}(t)=-x_{U}(t) \sin \eta \sin \theta+y_{U}(t) \cos \eta \sin \theta+z_{U}(t) \cos \theta \\
& p_{3}(t)=x_{U}(t) \sin \eta \sin \theta+y_{U}(t) \cos \eta \sin \theta+z_{U}(t) \cos \theta
\end{aligned}
$$

となる．各センサの検出信号 $p_{1}(t), p_{2}(t), p_{3}(t)$ から $\mathrm{x}$ 方向， $y$ 方向，z方向の振動成分 $x_{U}(t) ， y_{U}(t)$ および $z_{U}(t)$ が求められる。

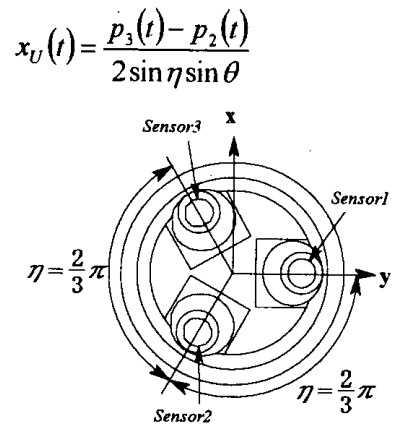

Fig. 3 Structural design of the hand-held type triaxial pickup 


$$
\begin{aligned}
& y_{U}(t)=\frac{2 p_{1}(t)-p_{2}(t)-p_{3}(t)}{3 \sin \theta} \\
& z_{U^{\prime}}(t)=\frac{p_{1}(t)+p_{2}(t)+p_{3}(t)}{3 \cos \theta}
\end{aligned}
$$

$2 \cdot 4$ 押当式3軸振動ピックアップの試作 前項で 述べた動作原理に基づく押当式の3軸振動ピックアッ プを試作した。交差角 $\theta$ は計測機器の大きさを考慮し て20度とした。図3に振動ピックアップの構造を示し， 図4に試作した振動ピックアップの外観を示す.試作し た振動ピックアップは せん断型センサ素子を チタンブロックに取り 付けた，3個のセンサ素 子の結合状態は $1 \mathrm{kHz}$ での振動数範囲内で剛 体とみなすことができ る.

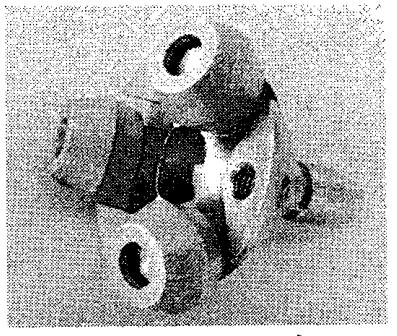

Fig. 4 Appearance of prototype pickup

試作振動ピックアップは押し当て方向を $z$ 軸とし，そ れに直交する方向をx軸およびy軸とした。試作振動ビ ックアップの接触共振振動数は水平方向の $x, y$ 軸で $5.2 \mathrm{kHz}$ ，垂直方向のz軸で $3.5 \mathrm{kHz}$ であった。接触共振振 動数の1/3の範囲の $1 \mathrm{kHz}$ までは平坦特性と見なすこと ができる。試作振動ピックアップのz軸を中心軸にして 回転して測定した $y$ 軸方向の指向特性は士70度の範囲 で土5.0\%以内で $\cos$ 曲線に合致したが，90度方向の横 感度は $8.0 \%$ となり, 従来の単軸の振動ピックアップの 横感度 $5.0 \%$ 以下に比べると若干劣っているが，実用的 には問題のない性能である。

\section{3. 軌跡振動計}

押し当て3軸ピックアッブを搭載した $10 \mathrm{~Hz} か ら 1 \mathrm{kHz}$ までの振動数範囲を测定できる振動計を開発した。開 発した振動計の概観を図5に示す。測定したデー夕を 128 ドット×64ドットの夜晶に表示する。表示は図6に 示すように数值表示と軌跡表示である。左の数值表示 はフルスケール $100 \mathrm{~mm} / \mathrm{s}$ までの3方向それぞれの振動 速度と，それらを合成した振動速度の4項目を表示する。 合成值は方向性のないスカラ一量であり，振動ピック の押し当て方向に依存しない量である。

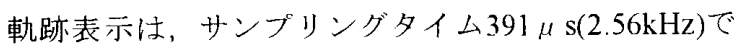
1024 デ一夕を採取して変位変換在行い表示する。図6 の右に軌跡の表示例を示す。

試作した振動計は，3方向の振動と回転計からのバル スなど参照用の信号と共に8点までの波形情報を記憶 させる機能を有する。この波形情報はパソコンにダウ ンロードして空間情報処理のデータとして使われる。

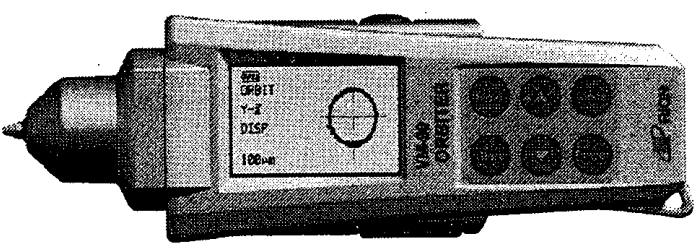

Fig. 5 Orbit visualizing vibrometer
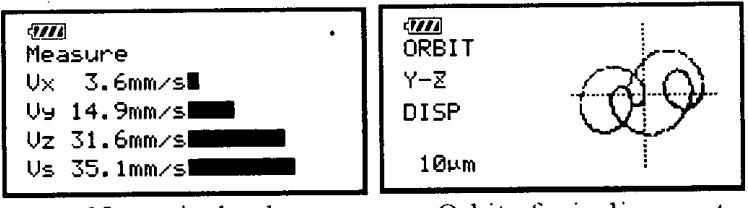

Numerical value

Orbit of misalignment

Fig.6 Example of display

\section{4. 三次元表示}

本項は開発した振動計の測定データの空間情報処理 に関して述べる。図7〜9の事例データはパソコンにダ ウンロードしてからFFT解析を行ったものである。この 事例デー夕はモーターと負荷の間を図10に示すカプラ

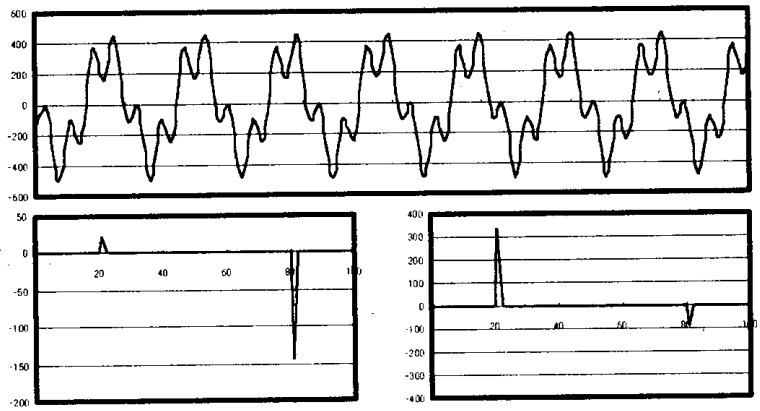

Real part

Imaginary part

Fig 7 Waveform and FFT spectrum of $x$-axis vibration

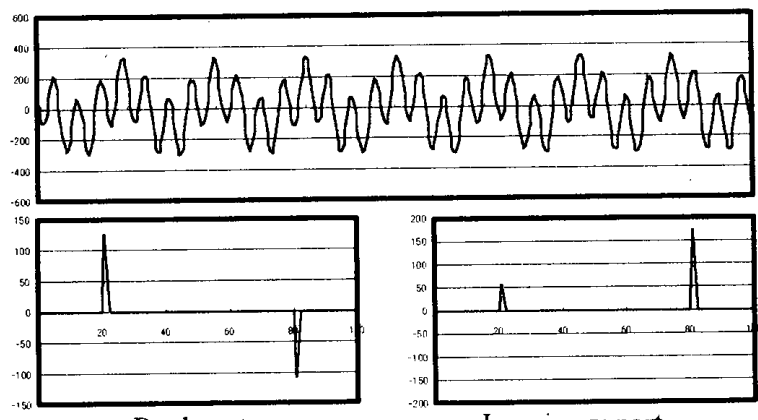

Real part

Imaginary part

Fig. 8 Waveform and FFT spectrum of $y$-axis vibration

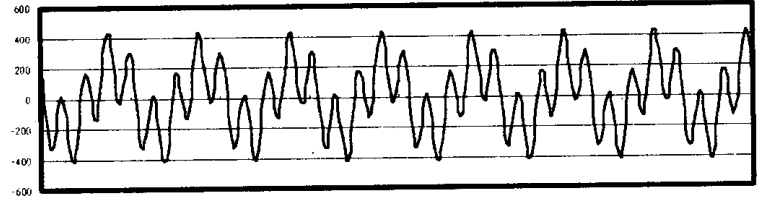

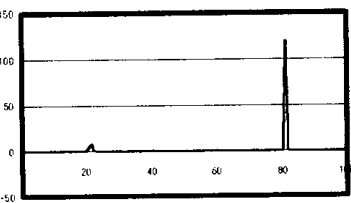

Real part

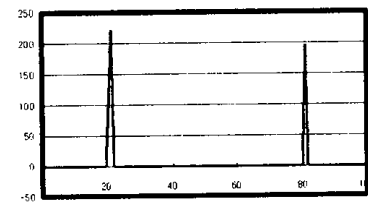

Imaginary part
Fig.9 Waveform and FFT spectrum of $z$-axis vibration 


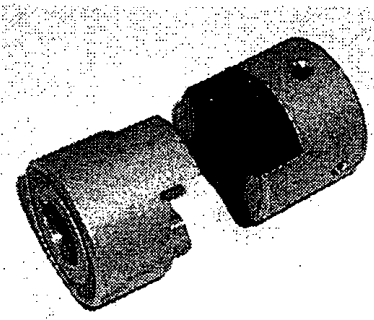

Fig.10 Experiment coupling

一を用いて結合した回 転機械のミスアライメ ント状態のものである。 図7は $x$ 軸方向の振動波 形とFFT解析による実数 部と虚数部のデータで ある，同様に図8はy軸の 振動データで, 図9は $z$ 軸 の振動データである. 回転数をNとすると、これら $x, y$ ， $z$ 軸の振動は共に回転軸の回転数と同じ1Nの振動数と, その4倍の4Nの振動数から成っている。この4Nの振動 数の発生は使われたカプラーの構造に起因すると推定 できる。ここで得られた実数部と虚数部の回転数成分 および4N成分の值とそれから計算できるそれぞれの位 相を表にに示す。これらのデー夕は同時に測定されてお り，重要な空間情報として3軸間の位相情報を持ってい るが，従来この情報は見過ごされていて充分活用され ていなかった。

本項はこの3軸間の位相情報を活用する方法を提案 するものである. 図7〜9のFFT解析データを使って図11 に示すような三次元の軌跡とその動画を描くことは容 易である．軌跡画面は振動の動きを3軸同時に目で見ら れる利点はあるが，この画面からはさほど多くの新た

Tablel Parameters obtained by FFT analysis

\begin{tabular}{|l|c|c|c|}
\hline & $x$-axis & $y$-axis & $z$-axis \\
\hline $\begin{array}{l}\text { Real part } \\
\text { of 1N frequency }\end{array}$ & $x_{1 r}=21.90$ & $y_{1 r}=124.5$ & $z_{1 r}=9.46$ \\
\hline $\begin{array}{l}\text { Imaginary part } \\
\text { of 1N frequency }\end{array}$ & $x_{1 i}=331.0$ & $y_{1 i}=56.72$ & $z_{1 i}=218.9$ \\
\hline $\begin{array}{l}\text { Phase (radian) } \\
\text { of 1N frequency }\end{array}$ & $x_{1 \alpha}=1.505$ & $y_{1 \alpha}=0.428$ & $z_{1 \alpha}=1.528$ \\
\hline $\begin{array}{l}\text { Real part } \\
\text { of 4N frequency }\end{array}$ & $x_{4 r}=-143.3$ & $y_{4 r}=-107.3$ & $z_{4 r}=119.5$ \\
\hline $\begin{array}{l}\text { Imaginary part } \\
\text { of 4N frequency }\end{array}$ & $x_{4 i}=-85.55$ & $y_{4 i}=169.7$ & $z_{4 i}=196.2$ \\
\hline $\begin{array}{l}\text { Phase (radian) } \\
\text { of 4N frequency }\end{array}$ & $x_{4 \alpha}=-2.603$ & $y_{4 \alpha}=2.135$ & $z_{4 i}=1.024$ \\
\hline
\end{tabular}

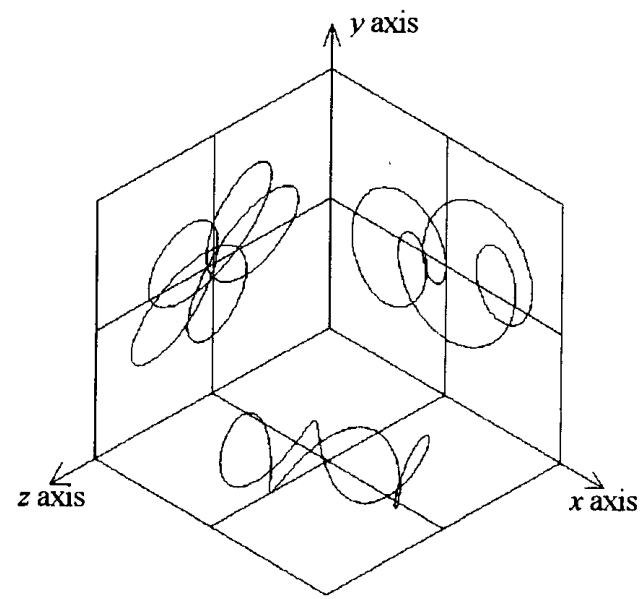

Fig.11 3-Dimensional display of orbit

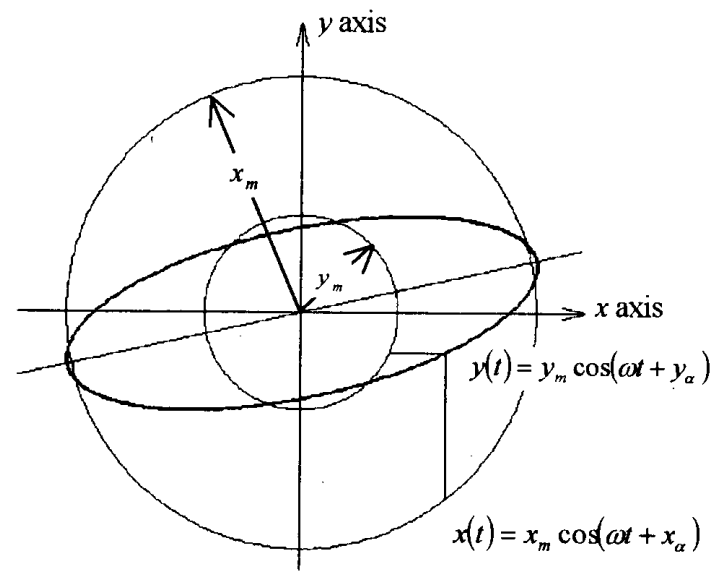

Fig.12 Elliptical orbit of a frequency component

な有益情報は得られない。軌跡画面は振動数成分がー 成分の場合は振動を目で見るだけで状況が把握でき る.だが，振動数成分が複数になる上その振動数成分 がほんの少し変化しただけでも全く異なる軌跡とな り，その変化を予測できない久点がある。したがって 複数の振動数の場合, 軌跡から異常原因の推定はでき ない上云える.

ある振動数において 2 方向の時間波形の軌跡は図 12 に示すように棈円形となる。これは横軸 $x$ 方向の振幅 $x_{m}$ 之縦軸 $y$ 方向振幅 $y_{m}$ の振幅が異なるためである. 著者らは， 振動数成分每に三次元空間でも楕円形のプレートで表 現できることに着目して，この棈円形の表示を基本表 示画面とする三次元空間振動情報処理手法を開発した. 図11と同じ測定データを使って図13のように振動数毎 の楕円形のプレートで表示できる。この椐円形プレー 卜は3軸の交点で拘束される。この画面では振動数成分 が複数の場合，振動数毎に方向と大きさの異なる棈円 形プレートで表示できる，特定の振動数成分が変化し ても他の振動数成分に影響を与えることがない：この 画面では振動数成分每に棈円形プレートの方位角と仰 角および傾きで振動の方向を表し，楕円形プレートの

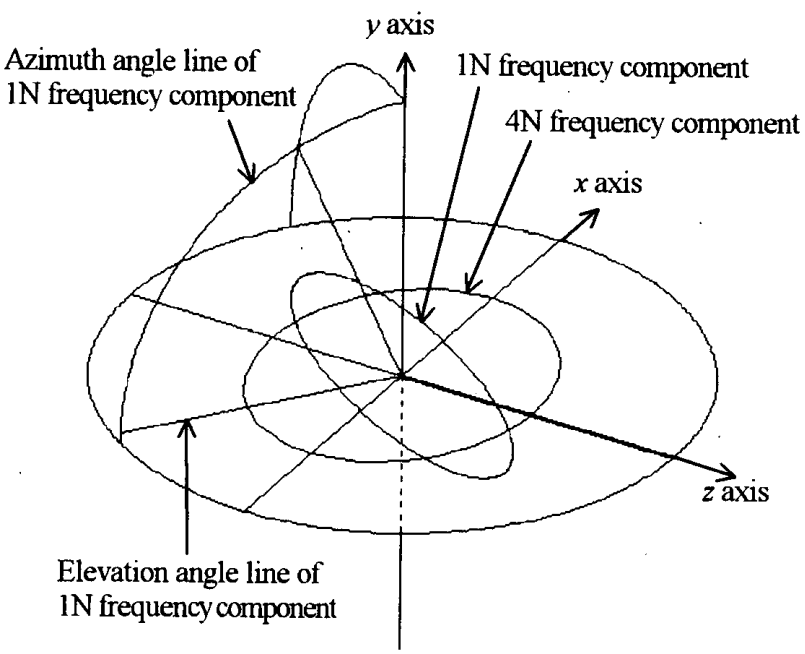

Fig.13 3-dimensional display of each frequency component 
大きさで振動の大きさを表す。表示の基本面を $x-z$ 面 として，y軸は上下方向とする.ここで，ある振動数 における $x$ 軸, $y$ 軸, $z$ 軸の振動の時間関数は

$$
\begin{aligned}
& x(t)=x_{r} \cos \omega t-x_{i} \sin \omega t=x_{m} \cos \left(\omega t+x_{\alpha}\right) \\
& y(t)=y_{r} \cos \omega t-y_{i} \sin \omega t=y_{m} \cos \left(\omega t+y_{\alpha}\right)
\end{aligned}
$$$$
z(t)=z_{r} \cos \omega t-z_{i} \sin \omega t=z_{m} \cos \left(\omega t+z_{\alpha}\right)
$$

である。ここで

$$
\begin{array}{ll}
x_{m}=\sqrt{x_{r}^{2}+x_{i}^{2}}, & x_{\alpha}=\operatorname{atn}\left(x_{i} / x_{r}\right) \\
y_{m}=\sqrt{y_{r}^{2}+y_{i}^{2}}, & y_{\alpha}=\operatorname{atn}\left(y_{i} / y_{r}\right) \\
z_{m}=\sqrt{z_{r}^{2}+z_{i}^{2}}, & z_{\alpha}=\operatorname{atn}\left(z_{i} / z_{r}\right) \quad \text { である. }
\end{array}
$$

方位角 $\theta_{a}$ は棈円が $x-z$ 面に交差する座標 $(x, z)$ 算出 することで求まる，棈円と $x-z$ 面の交点は $(18)$ 式の $y(t)$ がゼロの点であり， $\omega t=\pi / 2-y_{\alpha}$ の時に $y(\mathrm{t})$ がゼロにな る. その時の $x, z$ 座標は(17), (19)式から

$$
x_{a}=x_{m} \cos \left(x_{\alpha}-y_{\alpha}+\pi / 2\right)
$$

$z_{a}=z_{m} \cos \left(z_{\alpha}-y_{\alpha}+\pi / 2\right)$

となり， $z$ 軸を基準に方位角 $\theta_{a}$ は

$$
\theta_{a}=\operatorname{atn}\left(x_{a} / z_{a}\right)
$$

である。

$y$ 軸を中心に $x-z$ 面を方位角 $\theta_{a}$ 分回転させて新規の 座標軸にする。新規の $x-z$ 座標における $x, z$ 軸の時間 関数は

$$
\begin{aligned}
& x^{\prime}(t)=x(t) \cos \theta_{a}+z(t) \sin \theta_{a} \\
& z^{\prime}(t)=x(t) \sin \theta_{a}-z(t) \cos \theta_{a}
\end{aligned}
$$

となるが $y$ 軸の時間関数は変化が無く(18)式と同じ である。

仰角 $\theta_{e}$ は新座標で棈円が $y-x$ 面に交差する座標 $(y, x)$ を算出することで求まる。棈円と $y$ - $x$ 面の交点 は(24)式の $z^{\prime}(t)=0$ の点である.(24)式の

$$
z^{\prime}(t)=x_{m} \sin \theta_{a} \cos \left(\omega t+x_{\alpha}\right)-z_{m} \cos \theta_{a} \cos \left(\omega t+z_{\alpha}\right)=0
$$

を展開すると

$$
\left(x_{m} \sin \theta_{a} \sin x_{\alpha}-z_{m} \cos \theta_{a} \sin z_{\alpha}\right) \sin \omega t=
$$$$
\left(x_{m} \sin \theta_{a} \cos x_{\alpha}-z_{m} \cos \theta_{a} \cos z_{\alpha}\right) \cos \omega t
$$

となり,さらに

$$
\omega_{e}=\operatorname{atn}\left(\frac{x_{m} \sin \theta_{a} \cos x_{\alpha}-z_{m} \cos \theta_{a} \cos z_{\alpha}}{x_{m} \sin \theta_{a} \sin x_{\alpha}-z_{m} \cos \theta_{a} \sin z_{\alpha}}\right)
$$

が求まる。得られた $\omega_{e}$ の時にz'(t)がゼロになる，その 時の $y, x$ 座標は (18), (23)式から

$$
\begin{aligned}
& y_{e}^{\prime}=y_{m} \cos \left(\omega_{e}+y_{\alpha}\right) \\
& x_{e}^{\prime}=x_{m} \cos \theta_{a} \cos \left(\omega_{e}+x_{\alpha}\right)+z_{m} \sin \theta_{a} \cos \left(\omega_{e}+z_{\alpha}\right)
\end{aligned}
$$$$
\text { となり， } x \text { 軸を基準に仰角 } \theta_{e} \text { は }
$$

$$
\theta_{e}=\operatorname{atn}\left(y_{e}^{\prime} / x_{e}^{\prime}\right)
$$

である。

この表示はいわば振動数領域の三次元空間表示であ る、図14に表示画面例を示す，棈円プレートの円周を トレースする点の動きで回転方向を知ることができる。 この画面はy軸（縦軸）を中心に左右の回転と，画面上 でそのy軸に直交する左右の横軸を中心に上下に仰角 を自在に変えることができる。

画面の右上に上面から見た図と右下に真正面から見 た図を三次元空間の理解度を向上させるために追加表 示した。

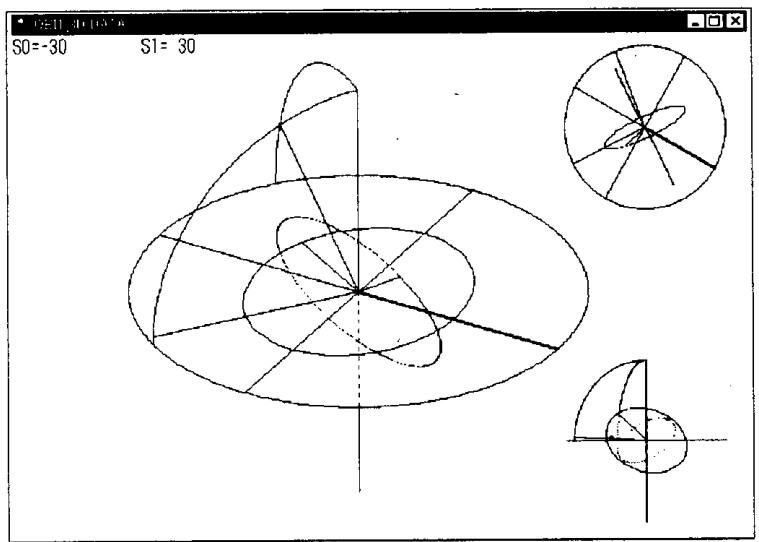

Fig. 14 Layout of 3-dimensional displays

\section{5. 棈円の分解処理}

前項で得られる三次元表示はFFTデータを基に振動 数毎の棈円プレートを描いたものである。これは，い わば振動数每に逆FFTを行い時間関数に戻して，その 軌跡を描いていることに等しい，棈円プレートの方位 角，仰角と大きさでその振動数の方向と振幅を視覚的 に理解することができるが，さらに処理能力を高める ために棈円形を直線形の振動と円形の振動に分解する. 同一の振動数であっても直線形の振動成分と円形の振 動成分は振動の発生メカニズムが異なることを想定し た。直線形江往復運動による振動成分であり共振や外 来の振動で振動要因が外部に依存するものであり直交 する2軸に同位相で寄与する成分である。円形は回転運 動による振動成分でアンバランスなど振動要因が内部 に依存すると見なすことができる成分であり，直交2軸 の間で互いに 本項ではこの棈円プレートの分解処理のアルゴリズ ムについて述べる. 解説のために前項の $x$ - $y$ 面の時間関 数を用いる. 水平軸を $x$ 軸とし，それに直交する垂直な 軸を $y$ 軸とする。

最初に，この棈円形の傾斜角 $\theta_{t}$ を算出する.用い るxおよび $y$ 軸の時間関数は(17)，(18)式である．原点から軌 跡点までの距離Dは

$$
\begin{aligned}
D^{2} & =x^{2}(t)+y^{2}(t) \\
& =x_{m}^{2} \cos ^{2}(\omega t+\alpha)+y_{m}^{2} \cos ^{2}(\omega t+\beta)
\end{aligned}
$$

であり、これを展開すると

$$
D^{2}=\frac{1}{2}\left[x_{m}^{2}+y_{m}^{2}+r \cos (2 \omega t+\lambda)\right]
$$


となる。ここで

$$
\begin{aligned}
& p=x_{m}^{2} \cos (2 \alpha)+y_{m}^{2} \cos (2 \beta), \quad q=x_{m}^{2} \sin (2 \alpha)+y_{m}^{2} \sin (2 \beta) \\
& r=\operatorname{sqr}\left(p^{2}+q^{2}\right), \quad \lambda=\operatorname{atn}(q / p) \quad \text { である. }
\end{aligned}
$$

(29)式は $\cos (2 \omega t+\lambda)=1$ のときに最大となる.

$\cos (2 \omega t+\lambda)=1$ 力口

$$
\omega t=-\frac{\lambda}{2}
$$

が導かれ，この值を(17)，(18)式に入れて算出される $x, y$ 点 が楕円の長軸の頂点の座標となり，棈円の傾斜角 $\theta$ ，は，

$\theta_{t}=\operatorname{atn}\left(\frac{y_{m} \cos (\alpha-\lambda / 2)}{x_{m} \cos (\beta-\lambda / 2)}\right)$

となる。

楕円振動は直線形の振動と回転の振動成分に分解で きるとして，(17)および(18)式を

$$
\begin{aligned}
& x(t)=a \cos (\omega t+\delta)+b \cos \theta_{t} \cos (\omega t+\gamma) \\
& y(t)=a \sin (\omega t+\delta)+b \sin \theta_{t} \cos (\omega t+\gamma)
\end{aligned}
$$

と置くことにする.

ここで $a \sin (\omega t+\delta)$ および $a \cos (\omega t+\delta)$ は回転による 振動成分の項である.

$b \cos \theta_{t} \cos (\omega t+\gamma)$ と $b \sin \theta_{t} \cos (\omega t+\gamma)$ は直線形による振 動成分の項であり， $x$ 軸と $y$ 軸に同形の波形として加算さ れる. (31)式，(32)式の右辺を展開すると

$x(t)=\left(a \cos \delta+b \cos \theta_{,} \cos \gamma\right) \cos \omega t$

$$
-\left(a \sin \delta+b \cos \theta_{t} \sin \gamma\right) \sin \omega t
$$

$y(t)=\left(a \sin \delta+b \sin \theta_{t} \cos \gamma\right) \cos \omega t$

$$
-\left(-a \cos \delta+b \sin \theta_{t} \sin \gamma\right) \sin \omega t
$$

が得られこれらから

$$
\begin{aligned}
& x_{r}=a \cos \delta+b \cos \theta_{t} \cos \gamma \\
& x_{i}=a \sin \delta+b \cos \theta_{t} \sin \gamma \\
& y_{r}=a \sin \delta+b \sin \theta_{t} \cos \gamma \\
& y_{i}=-a \cos \delta+b \sin \theta_{t} \sin \gamma
\end{aligned}
$$

の四つの式が得られる.この式から未知数である円形 振動の振幅 $a$, 直線形振動の振幅 $b$, 円形振動の位相 $\delta$, 直線形振動の位相 $\gamma$ を解く。(35) (38)式を用いて

$$
\begin{aligned}
& b \cos \gamma=\left(x_{r}+y_{i}\right) \cos \theta_{t}-\left(x_{i}-y_{r}\right) \sin \theta_{t} \\
& b \sin \gamma=\left(x_{r}+y_{i}\right) \sin \theta_{t}+\left(x_{i}-y_{r}\right) \cos \theta_{t}
\end{aligned}
$$

を導くことができる。さらに(39), (40)式から

$$
b=\sqrt{(b \sin \gamma)^{2}+(b \cos \gamma)^{2}}
$$

および

$$
\gamma=a \operatorname{tn}\left(\frac{b \sin \gamma}{b \cos \gamma}\right)
$$

が得られる，得られた $b ， \gamma の$ 值と(35), (36)式を用い ることで残りの $a ， \delta か ゙$ 解明される.

本項は $x-y$ 面を用いて解説したが, 図 13 の表示に適 用する場合は， $x, y, z$ 軸の空間を方位角と仰角に関して 回転処理を行い棈円プレートが $x$ - $y$ 面に移転してから 本項の処理を行う。

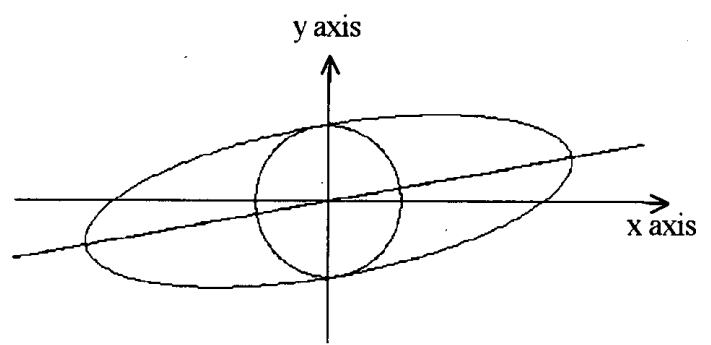

Fig. 15 Decomposed elliptical orbit to rectilinear vibration and round shape vibration

図 15 は図 13 の回転数成分の棈円プレートを分解処 理した事例であり，方位角と仰角を真正面に向けた表 示例である.斜めの直線は往復運動の振動成分であり， 円形は回転運動の振動成分である。ここでは比較の意 味で楕円プレートも描いているが, 円形の回転運動の 振動成分は棈円プレートに内接する円である，往復動 の振動の振幅が棈円の長軸より大きくなっているこ とが與味深い。

図 13 の分解処理事例を図 16 に示守. 図16の棈円 は図 13 の棈冈と異なり，見る方向で棈冈に見えるだ けであり，方位角と仰角を合わせて見れば円形である。 図16の上の図は回転数の成分と $4 \mathrm{~N}$ 成分の円形と直線 形を同時に表示しているが, 左下は回転数成分の直線 形々円形であり，右下は $4 \mathrm{~N}$ 成分の直線形と円形であ る、楕円を円形と直線形に分解したことにより表示画 面は複雑になり解り難い感はあるが, 円形の要素と直 線形の要素はそれぞれ振動の発生原因が別と考えら れることもあり，場合によっては有効である。

表1のFFTパラメータを用いて算出した三次元空間 の振動情報のパラメータを表 2 に示す.

図 13 および表 2 の例では回転数成分の方位角と $4 \mathrm{~N}$ の振動数成分の方位角が $85^{\circ}$ とほぼ直交しているこ

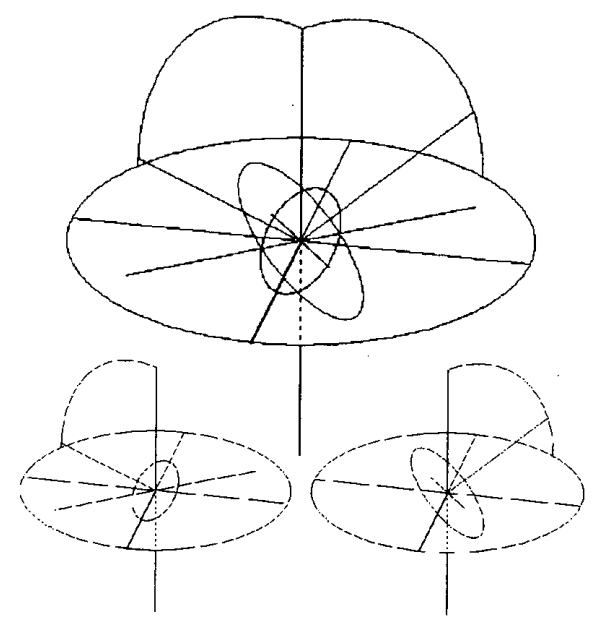

Fig. 16 Decomposed 3-dimensional display of Fig.13 to rectilinear vibration and round shape vibration 
Table 2 Vibration information parameters of 3-dimensional space

\begin{tabular}{|l|c|c|}
\hline & $\begin{array}{c}1 \mathrm{~N} \text { frequency } \\
\text { component }\end{array}$ & $\begin{array}{c}4 \mathrm{~N} \text { frequency } \\
\text { component }\end{array}$ \\
\hline Azimuth angle & $33.8^{\circ}$ & $-51.0^{\circ}$ \\
\hline Elevation angle & $2.1^{\circ}$ & $19.0^{\circ}$ \\
\hline Tilt angle & $-10.0^{\circ}$ & $-23.0^{\circ}$ \\
\hline $\begin{array}{l}\text { Amplitude of rectilinear } \\
\text { vibration }\end{array}$ & $52.2 \mu$ & $9.1 \mu$ \\
\hline $\begin{array}{l}\text { Amplitude of round shape } \\
\text { vibration }\end{array}$ & $11.9 \mu$ & $19.8 \mu$ \\
\hline
\end{tabular}

ることが興味を引く.1Nの成分はミスアライメントが 原因で発する振動であり，4Nの成分はカプラーの構造 から発する振動であると推定できる、ミスアライメン トの振動の仰角は $2.1^{\circ}$ と $x-z$ 面に近く軸ズレ方向に $52.2 \mu \mathrm{m}$ の振幅で直線形振動をしており, 方位角が $33.8^{\circ}$ と 45 度に近い傾きで振動をしている. $1 \mathrm{~N}$ 成分 の方位角と $4 \mathrm{~N}$ 成分の方位角の交差角と, $1 \mathrm{~N}$ 成分の方 位角は，物理的に最も自由に振動し易い方向に振動し ていることを示していると理解できる。このように， メカニズム的に振動数毎に振動源は独立であると考 える方が理に適っていると思われる，従って，このよ うな振動数毎にその振動状態を知ることは, 異常診断 の解析のための情報量としては極めて多大であると 考える。

\section{6. 結 論}

本論文では新たな原理による押当式3軸振動ピック
アップを提案し，その動作原理を述べた，そのピック アップを搭載した振動計を開発した. 次に3軸同時測定 で得られた振動データの三次元空間の振動情報の表示 方法と解析方法を提案し事例を示した。

三次元空間の振動情報の表示方法として振動数毎 に棈円プレートで表示する方法を提案した。振動の振 動数成分が三次元空間で棈円プレートを用いて表現す る，この方法はシンプルな画面に多くの情報を表現す ることができた。この表示により振動源の独立性が極 めて明確に表現できた。事例ではミスアライメントに よる振動の方向とカプラーによる振動方向は物理的に 振動し易い拘束性が弱い方向に振動していることを示 した。この事例によりミスアライメント時は軸方向に も振動が発生することが理解できる。

最後に，その棈円プレートをさらに直線形成分と円 形成分に分解する方法を提案した。この提案は振動源 として外部依存上内部依存台弁別するための一手法で あり，その有効性を説くには応用事例を重的る必要が あるが，今後の更なる改善と研究に期待する。

\section{文献}

1) 小村英智，横田明則，時田保夫，“押当式3軸振動ピ ックアップの開発”，日本音響学会誌, Vol.52, No.5, pp320-326(1996)

2) 小村英智，下村和広，芝田和雄，“簡易診断用押し当て 式軌跡振動計の開発”，日本機械学会 Dynamics \& Design Conference (2001.8), No.202 